\title{
THE EVALUATION OF THE PERCEPTION OF PSYCHOLOGICAL COUNSELING, POPULAR WITH TELEVISION SERIES, IN THE CONTEXT OF META FETISHISM: SAMPLE OF KIRMIZI ODA
}

\author{
Feridun NiZAM ${ }^{* 1}$ \\ *Dr. Öğr. Üyesi, Fırat Üniversitesi İletişim Fakültesi Radyo Televizyon ve Sinema Bölümü
}

\begin{abstract}
Since its emergence and widespread use as a mass communication medium, the entertainment function of television, in addition to its basic functions such as idealized education and information, continues to exist as indispensable practices. The most basic television content for the entertainment function is undoubtedly serials. In addition to this basic function, serials have been the most suitable presentation medium for commodity fetishism. In these examples of commodity fetishism, in which facts and events from every field of daily life can be seen as serial contents, serials in which psychological analyzes predominate have come to the fore. This study aims to explain the place of psychological counseling/psychotherapy in TV series and its relationship with commodity fetishism. The study is based on the analysis of Kırmızı Oda series, which was selected by purposive sampling method to examine the subject of fetishism, which has not been researched much in Turkish television. In this context, 'Kırmızı Oda', which was determined to reflect the phenomenon of meta fetishism, was chosen as a clear presentation of the psychological treatment process as the content of the series, from the universe consisting of TV series in which the psychological counseling profession and psychological analysis predominate. The aim of the study is to analyze how a private subject such as the patient-doctor relationship is used as a rating element and how it is handled as a commodity fetishism element in the related series. In addition, how the main character is depicted and how he is shown in a relationship with other people will be examined on the basis of the concept of fetishism. Before the analysis of the series, the concept of fetishism and commodity fetishism are also mentioned in order to provide a theoretical background. Kırmızı Oda series broadcast on TV8, one of the series on psychotherapy, was chosen as a sample. In the study, it was concluded that mental disorders and psychological disorders and related psychotherapies, which were generally considered as a situation comedy element in the previous periods, were fetishized for rating purposes simultaneously with the popularization of television series content.
\end{abstract}

Keywords: Meta Fetishism, Psychological Counseling, Tv Series, Kırmızı Oda

\section{TELEVIZYON DIZILERIYLE POPÜLERLEŞEN PSIKOLOJIK DANIŞMA ALGISININ META FETIŞiZMI BAĞLAMINDA DEĞERLENDIRILMESI: KIRMIZI ODA ÖRNEĞi}

\begin{abstract}
Özet
Kitle iletişim aracı olarak ortaya çıkışı ve yaygınlaşmasından beri televizyonun, idealize edilen eğitme ve bilgilendirme gibi temel işlevlerinin yanında eğlence işlevi de vazgeçilmez pratikler olarak varlığını sürdürmekte, hatta günümüz yayıncllık endüstrisinde eğlence işlevi diğer işlevlerin kat kat fazlası olarak öncelenmektedir. Eğlence işlevine yönelik en temel televizyon içeriği ise hiç kuşkusuz dizilerdir. Diziler bu temel işlevinin yanı sıra meta fetişizmi için en elverişli sunum mecrası olmuştur. Gündelik hayatın her alanına yönelik olgu ve olayların dizi içerikleri olarak görülebileceği bu meta fetişizmi örneklerinde, son dönemde psikolojik çözümlemelerin ağır bastığı diziler öne çıkmaktadır. Bu çalışma psikolojik danışma/ psikoterapinin günümüzde dizilerdeki yerini ve meta fetişizmi ile olan ilişkisini açıklama amacını taşımaktadır. Çalışma, Türk televizyonlarında çok fazla araştııımamış olan fetişizm konusunu incelemek için amaçı örneklem yöntemiyle seçilen Kırmızı Oda dizisi analizi üzerine bina edilmiştir. Bu çerçevede son dönemde artan psikolojik danışmanlık mesleği ve psikolojik çözümlemelerin ağır bastığı dizilerden oluşan evren içerisinden, psikolojik tedavi sürecinin net bir şekilde dizi içeriği olarak sunulduğu ve meta fetişizm olgusunu yansıttığı tespit edilen Kırmızı Oda örneklem olarak seçilmiştir. Çalışmanın amacı, ilgili dizide hasta-doktor ilişkisi gibi mahrem bir konunun rating unsuru olarak nasıl kullanıldığı ve bunun meta fetişizm unsuru olarak nasıl ele alındığının analiz
\end{abstract}

\footnotetext{
${ }_{1}^{1}$ Sorumlu yazar E-mail: fnizam@firat.edu.tr / 10.22252/ijca.977261
} 
edilmesidir. Bunun yanı sıra ana karakterin nasıl betimlenip diğer insanlarla nasıl bir ilişki içerisinde gösterildiği de fetişizm kavramı temelinde incelenecektir. Dizinin analizine geçmeden önce kuramsal bir altyapı sağlanması amacıyla, fetişizm olgusu ve meta fetişizmi kavramlarından da bahsedilmiştir. Örneklem olarak psikoterapi konulu dizilerden TV8 kanalında yayınlanan Kırmızı Oda dizisi seçilmiştir. Çalışmada önceki dönemlerde genellike durum komedisi unsuru olarak ele alınan ruhsal bozukluklar ile psikolojik rahatsızlıkların ve buna bağlı psikoterapilerin, televizyon dizi içeriği olarak popülerleşmesiyle eş zamanlı olarak, rating amaçlı fetişize edildiği sonucuna ulaşımıştır.

Anahtar Kelimeler: Meta Fetişizmi, Psikolojik Danışma, Tv Dizileri, Kırmızı Oda

\section{Introduction}

In today's consumption era, mass media have a very active role in ensuring the continuity of a systematic structure, especially by regulating social relations and then controlling the production and distribution processes. A false consciousness is created, false needs are produced, commodities are fetishized in this consumption-oriented world and people are made to believe that they have status as they consume. When evaluated in this context; Intermediaries such as radio, television, advertisement or cinema are seen as the most important means of imposition of imperative moods such as "consume, obey, die" imposed on societies. In this process, mass media reinforces the existing ideology, reproduces it or helps to produce consent.

The broadcasts of the media are effective in the formation of a homogeneous society. In this way, culture, which is the dynamic of the social structure, is industrialized and separated from its real context. Individuals who start to act en masse under the influence of mass media will tend to replicate each other and similarity will spread to all areas (Koçak and Küçük, 2021: 56). According to Adorno, who argues that the media makes individuals similar to each other, one of the most important features of mass media is mass formation. Adorno states that thanks to radio broadcasts, the masses are compared to each other and delivered to the ruling classes. The fact that it does this without using physical violence has made it so-called democratic in essence. Again, the mass media does not give the audience any right to reply due to its nature. It makes the audience addicted to itself with special broadcasts. Professionals who control media devices expertly guide the masses. The targeted audience may not even realize it. Thus, the media instills the consumer behavior they want to the masses by directing them. On the other hand, it does not impose consumer behaviors that do not suit it to the audience. There is a network structure within the media. This network structure is mostly based on consumption culture. Culture and art are intertwined in consumption culture. Again, everyone has been given a task so that no one will be left out of the system. The content produced by the media is quite simple. For example, at the beginning of a movie watched in the cinema, everything is easily predictable. It takes no effort to understand the movie. Because the created content is quite simple and shallow (Horkheimer and Adorno, 1996: 9-13). But the masses are not even aware of it. Industrialized consciousness creates false needs for itself. He searches for fake consumption over non-existent money. He finds logical excuses for his expenses. In one place, the consumer cannot even be aware of the changing consumption behaviors. They have now become consumers of popular culture.

\section{Conceptual Framework}

As a term, fetish (fetiche) is conceptually derived from the Latin words 'facticius', 'artificial' and facare 'to make' (Dayal, 2016: 4) and was primarily used in Portuguese, which passed from Portuguese to French (fei-tiço). ) concept is used in the sense of impressive and latent power, magic. While fetish means the object embodied by these features or the thing that occurs in those objects, it contains the substance "mana", which means mysterious and magical power in the language of the Polynesian people. While mana substance helps people in a healthy and happy life and production in a positive way, it also harms them with its negative side. Therefore, while mana is a phenomenon that should be avoided, people and objects loaded with mana should also be avoided. The most interesting existence of mana related to this work is that beauty is also a reflection of mana. The relationship of mana, which has penetrated into both magic and beauty, and fetish lies in the fact that both contain magic power at their core. The more fetish fascinates people, the more enchanting is beauty. From this point of view, it is possible to say that commodity fetishism and beauty are two structures that move hand in hand and bring the waters of life together in the same substance, and that their effects are a gift of manat substance, which has a substantial effect on people (Timuroğlu, 2013:142). 
Commodity fetishism, which Marx handled at the economic and social level and brought to a conceptual dimension, expresses the thing that sticks to the products of labor as commodities as soon as they leave the production line, similar to the fetishization of those objects with the supernatural powers ascribed to some objects in religion, which is therefore inseparable from commodity production. Marx, 2014:83). The main thing in commodity fetishism is to put a social value stamp on a product that is beneficial. In fact, this quality, which is the product of a valuation reached during the exchange process, derives from the meaning attributed to the capitalist mode of production rather than the commodity itself. This mysterious power attributed to commodities also provides an opportunity to fetishize the commodity.

According to Marx, the mysteriousness of the commodity as a fetish lies in the fact that it contains the social value of human labor. The fetish state of commodities, which are the products of labor, occurs in the social relations of commodities with each other rather than with their producer; however, it is not possible to say that the latent powers of commodities are an expression of self that will never come out of them. As Marx put it, "as soon as we move on to other modes of production, all the mysticism of the world of commodities, all the magic and mystery that creates a fog around the products of labor on the basis of commodity production, disappears" (Marx, 2014:86). In this context, the commodity that establishes hegemony over its producer by gaining an independent identity as soon as it enters the market may lose this dominance and become an ordinary product in the presence of another commodity that can replace itself in the market, and may lose its magic of being a fetish object by depriving it of its latent power. From this point of view, it seems possible for commodities to lose their throne to another commodity that can come after them and more valuable in terms of value, just like the exchange transactions at the stage of exchange. This exchange relationship causes individuals to be attached to another commodity at any time in the fetishism of commodities, the continuous operation of the disposable system of capitalist societies, which foresees the formation of short-term commodities, and the continuity of the visibility of commodities flying in advertisements.

It can be thought that the aesthetic orientation of the commodity and marketing strengthens the connotation of commodity fetishism. As soon as the mana substance conceptually contained in fetishism coincides with the aesthetic concern of the commodity and marketing, the commodity that has imprisoned the beautiful in its content is under its influence. In the face of this magic, the individual neutralizes himself and immerses himself in the mystery of the commodity, raises the commodity to a divine level with the excessive value and meaning he attributes to the product he has created, lowers his own value and alienates himself from the commodity. It should not be ignored that the dynamics that serve the culture industry such as today's advertising, media and art also make a significant contribution to convincing the consumer that the objects of production are sellable or equipped with magical features (Dayal, 2016: 2).

The largest area that should be used for the marketing of the produced brands and images is the media. As Kıymet Giray said, new fetishes; fashion is fed by mass media, industrial and science fiction sources, cinema, television, radio, newspaper, magazine and especially advertisements... The objects introduced are stuck in people's memories, from cars to gasoline, from ice cream to hamburgers, from cigarettes to drinks, from clothes to socks and underwear, and from banks to cinemas. everything is promoted through the world of advertising. Cinema artists, pop music artists, heroes of television series, comic book heroes and state leaders are also becoming new deities (Giray, 1995:62).

TV series not only tell drama, but also determine global thought patterns and tastes. TV series offer us role models, these role models are similar in almost all TV series. It builds a housemaid, a businessman, or a college student working in a luxurious house, out of standardized selves. Although the channels or platforms of the series are different, the content produced is the same. The same content is produced by different players.

The production of TV series with the same content on Turkish television for years is an example of this. In the researches, mafia, intrigue-based or psychological analyzes predominate. The favorite series of the participants was Çukur, which was broadcast on Show TV on Mondays. This is followed by the Kırmızı Oda and Yasak Elma series.

Mafia, intrigue, comedy, etc. Although such TV series are known as TV series that have been preferred by the audience for years and are thought to bring popularity, TV series in which psychological counseling profession and psychological analysis predominate appear as a new type of TV series on Turkish television (Koçak, 2021: 1106).

\section{Meta Fetishism with the Sample of Kırmızı Oda}

In this research, it is aimed to examine the Kırmızı Oda series, which contains a new fetish element, through television. Accordingly, the episodes of the series were tried to be explained by watching. 
Visual elements are frequently used both in observing the client-therapist relationship and in establishing the therapeutic bond in areas such as social work, psychology, psychiatry and family counseling. In this way, an empowering effect can be obtained in areas such as thinking, feeling, and ultimately gaining insight into life's ups and downs, both for clients, professionals working in this field, and students. Because visual elements such as movies and TV series quickly reach very strong emotions and bring them to the surface like a magnet. For example, it has been shown that visual elements are effective in helping people in areas such as anxiety, addiction, depression, domestic violence, bereavement, panic disorder, social phobia, body dysmorphic disorder, eating disorders and trauma-related disorders (Sharp, Smith, \& Cole, 2002: 270). ). In this direction, movies and TV series are also used as an educational tool.

Cinema and television is an art and entertainment field rather than an educational medium. For this reason, it is natural for the audience to focus on having a good time rather than the accuracy of any fact included in its content. This focus naturally simplified a complex field such as counseling/psychotherapy and reduced it to popular entertainment.

The image of mental health worker, which is mainly used in Turkish television, especially in sitcoms, is mostly presented as a comedy element. For example, psychologist scenes are included in popular products such as the Stranger in the House, Children Don't Hear, Lie World, King of the Realm, and the sketch program named Thank You. In addition, psychologists and psychiatrists from mental health professionals are seen in other popular TV series such as Hayat Şarkısı, Behzat Ç., Shattered, Suspect, Galip Derviş, Kördüm and many other productions. The popular web series $\mathrm{Fi}$ is a production starring a famous psychologist with problems. In addition, there are episodes that receive psychological support in the Çukur series, which is among the most popular TV series in the above-mentioned research, and in the special episode shot due to the pandemic seen in our country in 2020, Koçavalı Brothers meet with the psychiatrist via teleconference. They have fun conversations with the expert they call the 'Mad Doctor'. It is noteworthy that the time spent at home has increased due to the pandemic and that a psychiatrist is featured in the special episode of the series in this period when people are having mental and psychological difficulties.

As a matter of fact, when the findings of the studies are evaluated in general, mental health professionals are seen as individuals who are alienated from the society and have low professional competencies in the movies. Mental health professionals represented in the films mostly cannot solve their own problems, are helpless in the face of problems with their knowledge and techniques, and have low competence and coping skills. In movies, counseling/psychotherapy is featured with intense stigma. Individuals with psychological problems are generally of weak character, low coping skills and excluded from society. In addition, while psychological counseling/psychotherapy is defined as an expensive and luxurious intervention area belonging to the upper economic class, it emphasizes that it is an expensive intervention. When we look at the films in terms of ethical problems, the emphasis is that mental health professionals do not sufficiently comply with ethical boundaries. Especially the confidentiality of the client's information and not informing beforehand about the counseling/psychotherapy process are the most common ethical problems. While mental health professions are mostly defined as psychiatrists in films, some films also include discussions of field confusion (Gençoğlu, 2019:2219).

Since 2017, Dr. Gülseren Budaıcıoğlu's books are adapted as serials. The serials that have become a commodity are the same in terms of examining the situations related to the psychological counseling profession. Her book, "Hayata Dön", lasted for 3 seasons on Star TV with the title 'Istanbullu Gelin' (2017). The TV series "Doğduğun Ev Kaderindir", which started on TV 8 in 2019 and continued for 2 seasons, was adapted from the work of Gülseren Budaıcıoğlu's "Camdaki Kız". The series named Masumlar Apartmanı, which started on TRT 1 Channel in 2020, is based on Gülseren Budaıcıoğlu's novel Madalyonun İçi, from the 'Çöp Apartman' section. Another adapted from Gülseren Budaıcıoğlu's novel of the same name, the TV series "Camdaki Kız" started on Kanal D in 2021. Except for the İstanbullu Gelin, these series are aired on three different televisions four days a week in the same season. And while TV series adapted from the same author's books for the first time in Turkey are among the television series broadcast in prime-time, they are always at the top of the rankings (gazetevatan.com).

The data of the research consisted of the first 30 episodes of the Kırmızı Oda series, which was broadcast by TV8 channel in approximately 120-140 minutes episodes once a week in 2020. Episodes of the series were watched on the TV 8 Channel website (www.tv8.com.tr). The reason why this series was chosen for the research is that it contains rich examples of important issues (such as bilateral relations, confidentiality and confidentiality, professional responsibility) related to the ethics of psychological counseling. And, when 
compared to other TV series, the fact that the counseling sessions conducted by a psychologist with his clients take place in a simple room makes it easier for us to see the psychologist-client relationship clearly.

In the series, which is broadcast once a week at 120-140 minutes, each episode is a separate session, psychological counseling sessions with different clients are discussed. Although there are 4 psychological counselors (Doctor Hanım, Doctor Piraye, Doctor Deniz and Doctor Ayşe) working in the same clinic in the series, the main element of the series is that Doctor Hanım, who is the owner of the Manolya Psychiatry Clinic and a psychiatrist (in the later parts of the series, tells a client that the name of the female psychiatrist is Manolya). attention will be drawn to his relationship with his patients.

The clients of the Kırmızı Oda are as follows:

"a) Alya, with her strange character and behavior, despite graduating from law school with first place;

b) Mehmet, who is trying to cope with his anger problem;

c) Meliha, who is trying to hold on to life after her suicide attempt;

d) Salih and his friend Garip, whose life changes when they win the lottery, the sessions continue with the casino manager Garip...

e) Selvi, who explained why she couldn't leave the house after she was married to 50-year-old Rıza when she was a child, by her parents;

f) Boncuk, who during her hallucinations, claimed to be talking to the saints, breaking her ties with reality;

g) Kumru, who was raped by her stepfather as a child;

h) Doctor Ayşe, working in the same clinic;

i) Nazlı and Recai, a mismatched marriage, who came to the clinic for couples therapy,

j) Lad Sadi (Delikanlı Sadi), suffers from panic attacks,

k) Nihal, who says that she has a happy life with her husband Zafer and that she cherishes him, and her husband Zafer, who says that she cannot forget her ex-love and is unhappy,

I) Mr.Vahit, who is Zafer's father but fell in love with his son, the same woman who's name is Mitra, suffers from bipolar disorder" (www.tv8.com).

In recent years, the use of popular movies and TV series as catalysts in the psychotherapeutic process has gained increasing support both for individuals and families who participate in the therapy process as clients and for professionals who carry out the therapy process. In terms of helping clients to communicate with their suppressed emotions, instilling hope, recognizing individuals who have similar problems with themselves, and helping them to understand the problems of others; For professionals, films and TV series have the ability to communicate with the audience through images, symbols and metaphors in terms of teaching and development of counseling skills in perceptual and conceptual aspects, and realizing their own selves/self (Pak \& Öztürk, 2019:1202). The example of the Kırmızı Oda has also produced positive results for clients and those engaged in this profession. A little girl who watched the series in real life confessed that she had experienced similar events to the character of Kumru, one of her clients (www.aksam.com).

The 'crazy' 'insanity', etc., made by the society for those who receive psychological support with the series. Contrary to stigma, it is shown that mental health can deteriorate just like every person's physical health, and it is very "normal" to go to the doctor for this. Psychology series created awareness in the society, many people in Turkey met with a therapy room or therapy session for the first time thanks to this series, etc. There are psychologists who criticize the series, as well as psychological counselors who are thinking (www.bbc.com). While examining these views, it should not be forgotten that TV series and movies also have a commercial dimension.

Most of the mental health professionals shown in the series, which has turned into a commodity and contains fetishism, cannot solve their own problems, are helpless in the face of problems with their knowledge and techniques, and have low competence and coping skills. As a matter of fact, doctors have problems with family life, relationships and childhood. In a few episodes of the series, Doctor Ayşe appeared as the client of the Doctor lady.

The emotional bonds established with the clients in the series; using expressions such as -"I like you" or -"I don't like you", facial expressions that he cannot hide his feelings while listening to your story, sometimes 
laughing together and sometimes crying together, drinking coffee together, etc. They are professional ethical violations and are not experienced in real-life therapy sessions. When the person watching the series thinks that they will experience these, when they go to get help from an expert, they may experience disappointment and leave the expert in a difficult situation. Although these examples, which can be easily given in the fictional world of television, are criticized as severe ethical violations in real psychotherapy, they are almost appreciated by the audience as examples of fetishism.

In the series examined, we come across psychological counseling/psychotherapy as an expensive and luxurious intervention area. In the movies, especially when middle- and low-income individuals receive psychological counseling/psychotherapy, the dialogues about the price reinforce the implication that it is an expensive and luxurious intervention. When we look at the Kırmızı Oda clients, we see that most of them are rich. Among the signs of the emphasis on expensiveness and luxury, the place and the attentive and harmonious clothes of the psychiatrist and the accessories they use can be shown.

\section{Conclusion}

Mental disorders, which are more frequently covered on television after the 2000s in Turkey, were handled as a sitcom and the mass culture was provided to have a good time. With these series, which are products of popular culture, the individual resembles the character he watches or finds a piece of himself. Even a serious condition such as psychological diseases has taken place in the consumption culture. A worldview has emerged in the audience that only the rich can receive therapy as clients, and that even the problems of the rich are ridiculous for the poor.

The commodities created by the consumption culture have been fetishized, and certain patterns have been formed in the society, and those who do not fit this mold have been excluded by the society. While a woman who does not buy new clothes and does not go to the hairdresser can be seen as a freak by the society, the same woman can gain status in the society by going to the hairdresser and shopping. Although the story in Kırmızı Oda series and sometimes the story in the scenario supports this view with the beautiful women and well-groomed male characters they watch, it has succeeded in raising awareness in the audience by trying to show the profession in the serial sector in the closest way to reality.

The emotional bonds established with the clients in the series; using expressions such as -"I like you" or -"I don't like you", facial expressions that he cannot hide his feelings while listening to your story, sometimes laughing together and sometimes crying together, drinking coffee together, etc. They are professional ethical violations and are not experienced in real-life therapy sessions. When the person watching the series thinks that they will experience these, when they go to get help from an expert, they may experience disappointment and leave the expert in a difficult situation. Although these examples, which can be easily given in the fictional world of television, are criticized as severe ethical violations in real psychotherapy, they are almost appreciated by the audience as examples of fetishism.

\section{References}

Dayal, İ. (2016). Fotoğrafta Fetiş Nesne Kullanımı, Yayımlanmamış Yüksek Lisans Tezi. İstabul: Marmara Üniversitesi GSE.

Gençoğlu, Cem (2019). Türk Sinemasında Psikolojik Danışma/Psikoterapi Algısı. Turkish Studies - Social Sciences Volume 14 Issue 5, 2019, p. 2203-2224.

Giray, Kıymet; "Fetiş Nesneler, Nesne Kadınlar”, Türkiye'de Sanat Dergisi, sayı:17, 1995: 62-67

Horkheimer, Max ve Adorno, Theodor (1996). Aydınlanmanın Diyalektiği. (çev. Oğuz Özügül), İstanbul: Kabalcı Yayınevi.

Koçak, Can Mevlüt (2021). Medya, Kültür ve Benzeşme Bağlamında Bir Araştırma/ Uluslararası Sosyal Araştırmalar Dergisi / The Journal of International Social Research Cilt: 14 Sayı: 77 Nisan 2021.

Koçak, Can Mevlüt ve Küçük, Olgun (2021). Medyanın Kültüre Etkisi Üzerine Bir Araştırma. Journal of humanities and tourism research (Online), vol.11, ss.53-65

Marx, K. (2014). Kapital 1. Cilt. Sermayenin Üretim Süreci. N. Satlıgan ve M. Selik (çev.). (8. Baskı). İstanbul: Yordam Kitap. 
Pak Merve ve Beliz Öztürk (2019) Yapısal Aile Terapisi Kuramı Ekseninde ‘'̇stanbullu Gelin’ Dizisinin Analizi / Uluslararası Sosyal Araştırmalar Dergisi Cilt: 12 Sayı: 65

Sharp, C., Smith, J. V., \& Cole, A. (2002). Cinematherapy: Metaphorically promoting therapeutic change. Counselling psychology quarterly, 15(3), s. 269-276

Timuroğlu, V. (2013). Estetik. İstanbul: Berfin Yayınları.

www.aksam.com.tr Diziyi izlerken ağlamaya başladı... Kırmızı Oda Kumru'nun hikayesi gerçek oldu! (aksam.com.tr) / E.T.30.06.2021.

www.bbc.com/turkce/haberler-turkiye_Kırmızı Oda: Psikologlar diziyi neden eleştiriyor? - BBC News Türkçe/E.T.29.06.2021

www.gazetevatan.com.tr 'Camdaki Kız' başlıyor! Türk televizyon tarihinde bir ilk.../E.T.04.06.2021

www.tv8.com.tr/kirmizi-oda /E.T.20.06.2021 